\title{
A Dual Approach to Fostering Under-Prepared Student Success: Focusing on Doing and Becoming
}

\author{
Suzanne C. Shaffer, MSEd, MEd \\ Instructional Designer \\ Penn State York \\ Barbara E. Eshbach, MLS \\ Head Librarian \\ Penn State York \\ Jorge A. Santiago-Blay, PhD \\ Research Associate \\ Smithsonian Institution's National Museum of Natural History
}

\begin{abstract}
A paired course model for under-prepared college students incorporates a dual instructional approach, academic skill building and lifelong learning development, to help students do more academically and become stronger lifelong learners. In a reading support course, students improved their reading skills and applied them directly to the paired content course. They also developed lifelong learning attributes through increased self-knowledge (using the Effective Lifelong Learning Inventory), reflection, and coaching. Students showed significant gains in lifelong learning, an $85 \%$ success rate in the paired content course, and a higher retention rate than students outside the project with similar SAT critical reading scores.
\end{abstract}

Student college under-preparedness is often addressed by offering an array of skills-based remediation courses. Over time, research has shown that this approach often does not produce the desired outcomes (Clotfelter, Ladd, Muschkin, \& Vigdor, 2014; Santiago-Blay, Shaffer, \& Eshbach, 2015; Scott-Clayton \& Rodriguez, 2012). Yet, what should colleges do when the problem of underpreparedness still exists? Could the problem be more complex than simply addressing the academic skills portion of the equation? This project sought to address the problem of college under-preparedness from two directions: first, to continue addressing weak academic skills; and second, to add an important new component to the mix, namely, to build up lifelong learning attributes that would support students as The main goal was they work to catch up academically. In the end, our student success, but project was concerned not only with what students what does it mean for could do academically, but also with whom they would students to succeed in become as learners. We chose a paired course model (reading support course paired with an environmental college?

science course) within which to incorporate this dual approach. We hypothesized that this approach would have a positive impact on student success as measured by success rates in the environmental science course, satisfactory retention rates, and increases in student scores on the Effective Lifelong Learning Inventory (ELLI), developed by Deakin Crick, Broadfoot, and Claxton (2004). Our initial findings are promising and an expansion of the model is planned.

\section{The Background and Literature Underlying the Project}

The constructs of student success, paired courses, reflective practice, lifelong learning, and reading as a mechanism for learning played key roles in the development of the project and are briefly discussed as they relate to the project. 


\section{Student Success}

The main goal was student success, but what does it mean for students to succeed in college? Terenzini and Reason (2005) built a comprehensive model that explains the influences on the major outcomes of college: learning, development, change, and persistence. The two main categories of influence that most impact the outcomes of college are: (a) pre-college characteristics and experiences that include academic and personal preparedness for college (among others) and (b) the college experience which involves the organizational context and individual student experiences in and out of the classroom (Reason, 2009). In order for students to succeed (i.e., to reach the stated outcomes) in college, the pertinent influences need to be addressed. The current project attempted to address both pre-college characteristics (academic and personal preparedness) and the organizational context through which change could happen (the paired course model). For many students in this project, pre-college characteristics put them at risk on multiple fronts; including pre-existing science anxiety, academic under-preparedness, low socio-economic status, and first-generation status, as well as English Language Learner (ELL) issues. A major goal of the project was to be cognizant of these challenges and support students through effective course design that targeted both what students could do academically and the learner attributes they needed to become successful college students.

\section{Paired Courses}

A major influence on college success is the actual college experience, including both the organizational context and individual student experiences in and out of the classroom (Terenzini \& Reason, 2005). This project sought to maximize the impact of classroom experiences through careful planning of activities to foster stronger connections between the content of both the reading course and the environmental science course. Another goal was to encourage a sense of belonging through increased student-student and student-faculty interactions. This is especially important on a commuter campus where social connections can be hard to make. The paired course model provided greater opportunities for students to make these connections and receive support throughout the semester and beyond. The benefits of this type of paired course model are supported in the literature by Zhao and Kuh (2004) who describe the "added value" of learning communities, especially when "faculty members teaching the common courses structure assignments that require students to apply what they are studying in one course to other courses and assignments" (p. 116). This approach was a critical part of the design.

\section{Reflective Practice as an Avenue of Self-Discovery and Change}

Opportunities for reflection, coupled with meaningful conversations with caring faculty members, can help students make positive and powerful changes in their lives (Deakin Crick et al., 2004; Dzubak, 2013; Shaffer, in press). Jack Mezirow (1998) and others like Stephen Brookfield (1995) and Richard Paul and Linda Elder (2006), write about the power of critical reflection to transform lives. Through a cycle of self-knowledge, purposeful reflection, action planning, and coaching, students are given the tools they need in order to understand what works in their lives and what needs to change (Deakin Crick et al., 2004).

Mezirow (1998) discusses the important role of imagination in the reflective process - one's ability to imagine things differently from the current state. Ullmann, Wild, and Scott (2013) call reflection a "rare good" (p. 29) illustrating the benefits of reflective practice but at the same time pointing out the rarity of quality reflections. Direct instruction of effective reflective techniques helps students to constructively break free from negative patterns of behavior or self-defeating ways 
of interpreting the world to imagine new realities. Self-knowledge derived from ELLI scores and environmental science exam grades, meaningful reflective prompts, and effective faculty coaching provided students with an opportunity for selfdiscovery leading to positive change.

\section{Lifelong Learning Attributes}

A 2015 content analysis of 185 recent research articles on lifelong learning showed a resurgence of interest in this topic from educational researchers $(51 \%$ of the total studies) followed closely by business researchers $(43 \%)$ and other disciplines (Head, Van Hoeck, \& Garson, 2015). Research topics fell into four major categories including organizational climate, learner characteristics, market and social policies, and underserved populations. This demonstrates the interest in lifelong learning across a wide spectrum of human experience. Research in the United Kingdom, which is where we eventually found the lifelong learning measure, ELLI, led the way with $20 \%$ of the total studies.

We wanted students to develop positive traits as learners that would support them beyond their first semester in college. We chose ELLI, developed at the University of Bristol (UK) in 2004, because of its strength in differentiating between "efficacious, engaged, and energized learners and passive, dependent, and fragile learners" (Deakin Crick et al., 2004, p. 247). Exploratory factor analysis and scale reliability calculations were done across a large sample (approximately 10,000 students across 122 institutions and 413 classrooms) providing evidence of the scale's "stability, reliability, and internal consistency over time" to measure the seven dimensions of "learning power" (Deakin Crick \& Yu, 2008, p. 387). Student scores on ELLI provided a powerful starting place for discussion, reflection, and change.

\section{Reading as a Mechanism for Learning}

Students' declining reading ability is an important factor in their diminishing academic preparedness. In 2012, only $52 \%$ of U.S. high school graduates met the ACT's benchmark in reading, predicting success (with a $B$ grade or better) in their first year in college (Venezia \& Jaeger, 2013). Reading skills needed to prepare for contemporary careers are more complex than ever before. Becoming a competent reader today means continually developing over the lifespan, refining the ability to think critically and analytically about text, as well as continually evaluating a never-ending stream of information (Alexander \& Disciplined Reading Learning Research Laboratory, 2012). Students who enter college with low reading abilities are already at risk because of the very nature of college-level reading, which is higher in volume than students are used to and which also requires the ability to learn independently from more complex texts.

To help students acquire these higher-order reading skills, the course used a variety of approaches to address information processing, metacognition, and critical thinking (Karpicke, Butler, \& Roediger, 2009; Kashdan et al., 2009; Nosich, 2012; Shaffer, 2014; von Stumm, Hell, \& Chamorro-Premuzic, 2011; see Appendix). Students practiced these techniques in class and then integrated them into their weekly toolbox assignments using the environmental science textbook. The paired course model became a very effective strategy for helping students become stronger readers and learners through the direct application of learned skills into the environmental science content.

\section{The Model}

To address the dual areas of (a) academic skills, labeled as "doing", and (b) lifelong learning, called "becoming", we developed a six-credit paired course model in which under-prepared (identified through low SAT critical reading scores), full-time, first-year students were simultaneously enrolled in a college reading 
support course and an environmental science course. Reading skills and study strategies were taught and then applied during the reading course to the material in environmental science. The environmental science course was taught as a traditional lecture-based course with exams and assigned readings. Students could enroll in environmental science without also being in the paired reading course. These students served as the control group for lifelong learning comparisons. In addition to teaching academic skills in the reading course, lifelong learning skills were explicitly taught and integrated into reflective assignments and classroom activities. Success rates in the content course were tracked (exam grades and overall course grades) along with retention rates to determine if students completed the course successfully and were still enrolled for the next semester after the course offering. Changes in lifelong learning attributes were measured using ELLI, a 72item online self-report that measures dispositions in seven areas found to influence competence as an "intentional" learner: resilience, creativity, changing and learning, meaning-making, strategic awareness, critical curiosity, and learning relationships (Deakin Crick et al., 2004).

Reading course instructional strategies: Doing. Reading course instructional time was divided equally between academic skill building, as it applied to learning environmental science content, and lifelong learning skill development. The academic skill-building portion of the course addressed issues such as vocabulary development systems, information processing strategies, effective textbook reading, studying for exams, metacognition, and critical thinking. A typical lesson would include the introduction of several strategies related to the topic and an in-class demonstration of the application of the strategy, followed by a "toolbox assignment" that students would complete for the next class in which they applied the learned strategies to the environmental science content (see Appendix). Students enjoyed these assignments and reported a positive impact on their environmental science scores. One student commented in an electronic journal entry, "Some success that I have come across would be in my science class when I first started I thought that I wouldn't get a good grade in anything but later on I saw that all I have to do is apply myself . . . and then the material comes easy. All it takes is practice and not just throwing in the towel when the going gets tuff" (Student A, personal communication, December 5, 2013). Students found that successfully doing the work of college is possible with the right motivation, skills, and focus.

Reading course instructional strategies: Becoming. We wanted students to gain mastery of the environmental science content, but equally as important, we wanted them to develop positive traits as learners that would support them beyond their first semester in college. Students took ELLI during the first week of classes and received their scores in the form of a spider diagram (see Figure 2). The spider diagram allows students to see their initial profiles holistically as represented by their scores for the learning dimensions. When the postsemester scores are added, students then can see their growth in all seven

The academic skill-building portion of the course addressed issues such as vocabulary development systems, information processing strategies, effective textbook reading, studying for exams, metacognition, and critical thinking. dimensions as a comparison between the two concentric circles on the diagram. The class focused on a single dimension of ELLI for a twoweek period before moving onto the next element. Self-knowledge, reflection, and coaching were used to help students grow in each dimension. The first week, students completed activities and reflections about the lifelong learning element in their lives. The second week took on a more academic focus, with students making connections between the lifelong learning dimension and college life in general or the 
environmental course specifically (see Appendix). Over time, the goal was to encourage the development of a common language and practice of lifelong learning (Deakin Crick et al., 2004).

The lifelong learning portion of the course was very fluid, depending on what was happening in either paired course. The key element was to give students an opportunity to understand themselves as learners and then provide effective prompts that helped them uncover meaningful insights academically and personally (Brookfield, 1995; Deakin Crick et al., 2004; Dzubak, 2013; Mezirow, 1995; Shaffer, in press). Over time, most students identified significant changes in themselves. The process came to a climax during the last week of classes when students retook ELLI. The new spider diagrams showed concentric pre- and postscores which allowed students to see immediately their areas of growth since the beginning of the semester (see Figure 2). Electronic journal entries also captured this awareness about the important ways in which they had grown over the semester. One student who had struggled

To see students become proud, resilient, confident, and successful in spite of continuing challenges, was incredibly moving.

tremendously with both language and confidence wrote, ". . . at the beginning I though[t] I was the only one who was behind and didn't know a lot because [of] my language issue but I see now that everyone here is like me - they don't know everything as I though[t] and it help me to feel a little better of myself because I don't feel . . . less intelligent, so in this whole semester I learned different thing in area that I improve myself and no[t] give up . . . so on that way I feel proud [of] myself" (Student B, personal communication, December 5, 2013). As an instructor, it was very powerful to read these words. This particular student was also successful in the environmental science course which helps to illustrate the effectiveness of the model. To see students become proud, resilient, confident, and successful in spite of continuing challenges, was incredibly moving.

\section{Method}

\section{Participants}

Fifteen students consented to participate in the study from the paired course group and finished both courses. These students were first-year, full-time students. During new student orientation, these students were recommended to sign up for the reading course because of low SAT critical reading scores. An additional 18 students (from multiple class years and SAT profiles) completed only the environmental science course without the paired reading course and agreed to participate in the study. These 18 students served as the control group for ELLI score comparisons.

An Institutional Review Board (IRB) proposal was submitted and accepted to complete this study. Informed consent was completed and student permissions obtained in writing to use their data in the form of academic grades, ELLI scores, course satisfaction surveys, and journal entries.

\section{Procedure}

Students in both the study and control groups took ELLI during the first and last weeks of the semester. All students attended the three-credit environmental science course that met once per week. In addition to environmental science, students in the study group also attended the paired three-credit reading course that met twice per week.

In our statistical analysis, independent samples $t$-tests were computed using ELLI sub-scale scores for each dimension of lifelong learning for the study group (those in the paired courses) and the control group (those taking only environmental science without the supplemental instruction in the reading course) to identify any differences between groups before the study began (see Table 1). 
Table 1

Independent Samples t-test of Significance between Study Group and Control ELLI Scores Pre-Semester

\begin{tabular}{lcccccc}
\hline \multicolumn{1}{c}{ ELLI dimensions } & $p$ & $t$ & $\begin{array}{c}M \\
\text { control }\end{array}$ & $\begin{array}{c}S D \\
\text { control }\end{array}$ & $\begin{array}{c}M \\
\text { treatment }\end{array}$ & $\begin{array}{c}S D \\
\text { treatment }\end{array}$ \\
\hline $\begin{array}{l}\text { Changing and } \\
\text { Learning }\end{array}$ & 0.73 & -0.35 & 71.67 & 14.48 & 73.33 & 14.53 \\
$\begin{array}{l}\text { Learning } \\
\text { Relationships }\end{array}$ & 0.41 & -0.84 & 65.67 & 15.71 & 69.80 & 13.92 \\
Strategic Awareness & 0.90 & -0.12 & 58.89 & 14.82 & 59.48 & 14.50 \\
Resilience & 0.02 & 2.41 & 61.67 & 14.26 & 48.82 & 18.16 \\
Creativity & 0.35 & -0.94 & 51.67 & 15.17 & 56.43 & 15.47 \\
Meaning Making & 0.66 & 0.44 & 71.17 & 17.04 & 68.82 & 15.04 \\
Critical Curiosity & 0.99 & -1.00 & 50.21 & 20.52 & 50.24 & 21.17 \\
\hline
\end{tabular}

Note. $d f=35$

Paired samples $t$-tests were completed at the end of the semester to compare pre- and post-semester ELLI scores for the matched pairs in both control (see Table 2) and study (see Table 3) groups. Student success rates in environmental science were analyzed using descriptive statistics. Retention rates for students in the paired course model were compared to those from the same first-year class with similar SAT profiles who were not in the paired model. Anonymous, reading course satisfaction surveys were analyzed using descriptive statistics (see Table 4).

Table 2

Paired Samples t-test of Significance for Control Group ELLI Scores Pre-and PostSemester

\begin{tabular}{lccccccc}
\hline ELLI dimensions & $p$ & $\begin{array}{c}\% \\
\text { change }\end{array}$ & $t$ & $\begin{array}{c}M \\
\text { pre- }\end{array}$ & $\begin{array}{c}S D \\
\text { pre- }\end{array}$ & $\begin{array}{c}M \\
\text { post- }\end{array}$ & $\begin{array}{c}S D \\
\text { post- }\end{array}$ \\
\hline $\begin{array}{l}\text { Changing and } \\
\text { Learning }\end{array}$ & 0.63 & $3 \%$ & -0.49 & 70.88 & 14.44 & 73.68 & 23.14 \\
$\begin{array}{l}\text { Learning } \\
\text { Relationships }\end{array}$ & 0.68 & $-4 \%$ & 0.42 & 64.74 & 15.57 & 62.11 & 22.61 \\
$\begin{array}{l}\text { Strategic } \\
\text { Awareness }\end{array}$ & 0.33 & $8 \%$ & -0.99 & 59.36 & 15.08 & 64.18 & 18.52 \\
Resilience & 0.47 & $-7 \%$ & 0.74 & 61.05 & 14.38 & 57.02 & 20.53 \\
Creativity & 0.60 & $6 \%$ & -0.54 & 51.66 & 15.59 & 54.58 & 20.09 \\
Meaning Making & 0.69 & $-4 \%$ & 0.40 & 71.75 & 17.3 & 68.95 & 22.88 \\
Critical Curiosity & 0.47 & $12 \%$ & -0.74 & 48.68 & 19.89 & 54.39 & 23.09 \\
\hline
\end{tabular}

Note. $d f=18$ 
Table 3

Paired Samples t-test of Significance for Treatment Group ELLI Scores Pre-and Postsemester

\begin{tabular}{lccccccc}
\hline \multicolumn{1}{c}{ ELLI dimensions } & $p$ & $\begin{array}{c}\% \\
\text { change }\end{array}$ & $t$ & $\begin{array}{c}M \\
\text { pre- }\end{array}$ & $\begin{array}{c}S D \\
\text { pre- }\end{array}$ & $\begin{array}{c}M \\
\text { post- }\end{array}$ & $\begin{array}{c}S D \\
\text { post- }\end{array}$ \\
\hline $\begin{array}{l}\text { Changing and } \\
\text { Learning }\end{array}$ & 0.05 & $14 \%$ & -2.11 & 70.53 & 14.53 & 81.57 & 14.63 \\
$\begin{array}{l}\text { Learning } \\
\text { Relationships }\end{array}$ & 0.108 & $15 \%$ & -1.70 & 67.19 & 13.92 & 77.65 & 17.27 \\
Strategic Awareness & $<.001$ & $24 \%$ & -4.81 & 56.73 & 14.5 & 73.37 & 19.91 \\
Resilience & 0.027 & $20 \%$ & -2.42 & 48.77 & 18.16 & 59.61 & 14.58 \\
Creativity & $<.001$ & $40 \%$ & -5.61 & 53.8 & 15.47 & 75.82 & 16.98 \\
Meaning Making & 0.002 & $23 \%$ & -3.58 & 68.07 & 15.04 & 81.57 & 11.97 \\
Critical Curiosity & 0.005 & $54 \%$ & -3.23 & 48.47 & 21.17 & 65.2 & 16.92 \\
\hline
\end{tabular}

Note. $d f=15$

Table 4

End-of-Course (Reading Course) Satisfaction Survey ( $n=15$ )

\begin{tabular}{|c|c|c|}
\hline Question & Response & \\
\hline $\begin{array}{l}\text { How did you feel being part of a research } \\
\text { study? }\end{array}$ & $\begin{array}{l}\text { It was a good experience } \\
\text { Neither good nor bad }\end{array}$ & $\begin{array}{l}77 \% \\
23 \%\end{array}$ \\
\hline $\begin{array}{l}\text { Next year, should we keep - lose - or } \\
\text { modify the pairing with environmental } \\
\text { science? }\end{array}$ & $\begin{array}{l}\text { Keep it } \\
\text { Modify it - do it with more } \\
\text { courses }\end{array}$ & $\begin{array}{l}86 \% \\
14 \%\end{array}$ \\
\hline $\begin{array}{l}\text { Rate your overall experience with the } \\
\text { paired course }\end{array}$ & $\begin{array}{l}\text { Strongly positive experience } \\
\text { Difficult, but I saw the } \\
\text { benefits }\end{array}$ & $\begin{array}{l}79 \% \\
21 \%\end{array}$ \\
\hline $\begin{array}{l}\text { Next year, should we keep - lose - } \\
\text { modify the following course elements: } \\
\text { Cornell Notes \& applied reading } \\
\text { assignments }\end{array}$ & $\begin{array}{l}\text { Keep it } \\
\text { Lose it }\end{array}$ & $\begin{array}{l}86 \% \\
14 \%\end{array}$ \\
\hline ELLI & $\begin{array}{l}\text { Keep it } \\
\text { Lose it }\end{array}$ & $\begin{array}{r}93 \% \\
7 \%\end{array}$ \\
\hline Lecture $\&$ in-class activities & $\begin{array}{l}\text { Keep it } \\
\text { Modify it - more active } \\
\text { learning }\end{array}$ & $\begin{array}{l}86 \% \\
14 \%\end{array}$ \\
\hline $\begin{array}{l}\text { Would you advise a new student next } \\
\text { year to take the paired courses? }\end{array}$ & Yes & $100 \%$ \\
\hline
\end{tabular}

Note. Italics reflect student comments. 


\section{Results}

Our findings supported the hypothesis that creating an intervention for under-prepared college students that combined both academic skill-building and lifelong learning development support student success. The main findings from our data analyses are: (a) there were no statistically significant differences in ELLI scores at the beginning of the semester between the study and control groups (see Table 1), (b) students in the control group who received no explicit instruction in lifelong learning made no statistically significant gains in the ELLI scores pre- to post-semester (see Table 2), (c) students in the study group who participated in the paired course model and who received explicit instruction in lifelong learning made statistically significant gains in all areas of lifelong learning except Learning Relationships. It should be noted that Learning Relationships as a dimension was covered hastily at the end of the last week of classes, so this result is not surprising (see Table 3), (d) students were highly satisfied with the course model and components (see Table 4), (e) the retention rate from fall to spring was $84 \%$ for students in the study group as compared to $73 \%$ for a comparison group from the same entrance class with similar SAT profiles, and ( $f$ ) students in the study group had an $84 \%$ success rate (grade $C$ or better) in the environmental science course.

\section{Discussion}

This study has limitations due to the small number of participants in the initial study. However, student comments in both the journals entries and anonymous surveys suggest that the model is effective. Success rates in the environmental science course as well as the higher retention rates are also promising. These initial findings warrant future replications of the project which may strengthen the findings with time. Implications of the project include possible expansion to other programs and courses in order to reach more students. The model is fairly flexible and could be used as a framework for many types of paired courses, from First-Year Experience courses to summer bridge programs to support course pairings with many combinations of content courses. The results, while preliminary, do seem to be a promising combination for students. Designing a dual approach to help them do more academically and become stronger lifelong learners creates multiple lines of support that are mutually beneficial and produces, perhaps, more impact than using any one approach on its own.

\section{References}

Alexander, P. A., \& Disciplined Reading Learning Research Laboratory. (2012). Reading into the future: Competence for the 21st century. Educational Psychologist, 47 , doi: $10.1080 / 00461520.2012 .722511$

Brookfield, S. D. (1995). Becoming a critically reflective teacher. San Francisco, CA: Jossey-Bass.

Clotfelter, C. T., Ladd, H. F., Muschkin, C., \& Vigdor, J. L. (2014). Developmental education in North Carolina community colleges. Educational Evaluation and Policy Analysis. Advance online publication. doi: $10.3102 / 0162373714547267$
Deakin Crick, R., Broadfoot, P., \& Claxton, G. (2004). Developing an Effective Lifelong Learning Inventory: The ELLI project. Assessment in Education, 11, 247-272. doi:10.1080/0969594042000304582

Deakin Crick, R., \& Yu, G. (2008). Assessing learning dispositions: Is the Effective Lifelong Learning Inventory valid and reliable as a measurement tool? Educational Research, 50, 387402.

doi:10.1080/00131880802499886 
Dzubak, C. M. (2013, May 8). A purposeful pause: The role of active reflection in learning, Synergy, 6. Retrieved from Association for the Tutoring Profession website: http://www.myatp.org/resources/journa I/synergy-volume-6

Head, A. J., Van Hoeck, M., \& Garson, D. S. (2015). Lifelong learning in the digital age: A content analysis of recent research on participation. First Monday, 20(2). Retrieved from http://firstmonday.org/ojs/index.php/fm /article/view/5857

Karpicke, J. D., Butler, A. C., \& Roediger, H. L., III (2009). Metacognitive strategies in student learning: Do students practice retrieval when they study on their own? Memory, 17 doi:10.1080/09658210802647009

Kashdan, T. B., Gallagher, M. W., Silvia, P. J., Winterstein, B. P., Breen, W. E., Terhar, D.,Steger, M. F. (2009). The curiosity and exploration inventory-II: Development, factor structure, and psychometrics, Journal of Research in Personality, 43, 987-998. doi:10.1016/j.jrp.2009.04.011

Mezirow, J. (1998). On critical reflection. Adult Education Quarterly, 48(3), 185198. doi:10.1177/074171369804800305

Nosich, G. M. (2012). Learning to think things through: A guide to critical thinking across the curriculum. Boston, MA: Pearson.

Paul, R., \& Elder, L. (2006). Critical thinking: Tools for taking charge of your learning and your life ( $2^{\text {nd }}$ ed.). Upper Saddle River, NJ: Pearson Prentice Hall.

Reason, R. D. (2009). An examination of persistence research through the lens of a comprehensive conceptual framework. Journal of College Student Development, 50, 659-682. doi:10.1353/csd.0.0098
Santiago-Blay, J. A., Shaffer, S. C., \& Eshbach, B. (2015). SENCERizing a biology general education (gen-ed) course. Life: The Excitement of Biology, 3(1), 33-56. doi: 10.9784/LEB3(1)Santiago-Blay.02

Scott-Clayton, J., \& Rodriguez, O. (2012, August). Development, discouragement, or diversion? New evidence on the effects of college remediation (Working Paper No. 18328). Retrieved from National Bureau of Economic Research website: http://www.nber.org/papers/w18328

Shaffer, S. C. (2014, July 18). ELLI integration [Video file]. Retrieved from https://www.youtube.com/watch?v=gK5 I_68g0X

Shaffer, S. (in press). Building student capacity for reflective thinking. The Common Good: A SUNY Plattsburgh Journal on Teaching and Learning.

Terenzini, P. T., \& Reason, R. D. (2005, November). Parsing the first year of college: A conceptual framework for studying college impacts. Paper presented at the meeting of the Association for the Study of Higher Education, Philadelphia, PA. Retrieved from

http://www.augustana.edu/Documents/i r/Parsing\%20-\%20Framework\%20 ASHE05ptt.pdf

Ullmann, T. D., Wild, F., \& Scott, P. (2013). Reflection: Quantifying a rare good. In M. Kravcik, B. Krogstie, A. Moore, V. Pammer, L. Pannese, M. Prilla, ... T. D. Ullmann (Eds.), Proceedings of the 3rd Workshop on Awareness and Reflection in Technology-Enhanced Learning in Conjunction with the 8th European Conference on Technology Enhanced Learning: Scaling Up Learning for Sustained Impact (pp. 29-40). Retrieved from http://ceur-ws.org/Vol1103/

Venezia, A., \& Jaeger, L. (2013). Transitions from high school to college. The Future of Children, 23(1), 117-136. doi: $10.1353 /$ foc. 2013.0004 
von Stumm, S., Hell, B., \& ChamorroPremuzic, T. (2011). The hungry mind: Intellectual curiosity is the third pillar of academic performance. Perspectives on Psychological Science, 6, 574-588. doi: $10.1177 / 1745691611421204$
Zhao, C., \& Kuh, G. D. (2004). Adding value: Learning communities and student engagement. Research in Higher Education, 45(2), 115-138. doi: $10.1023 / \mathrm{b}:$ rihe. 0000015692.88534 .de

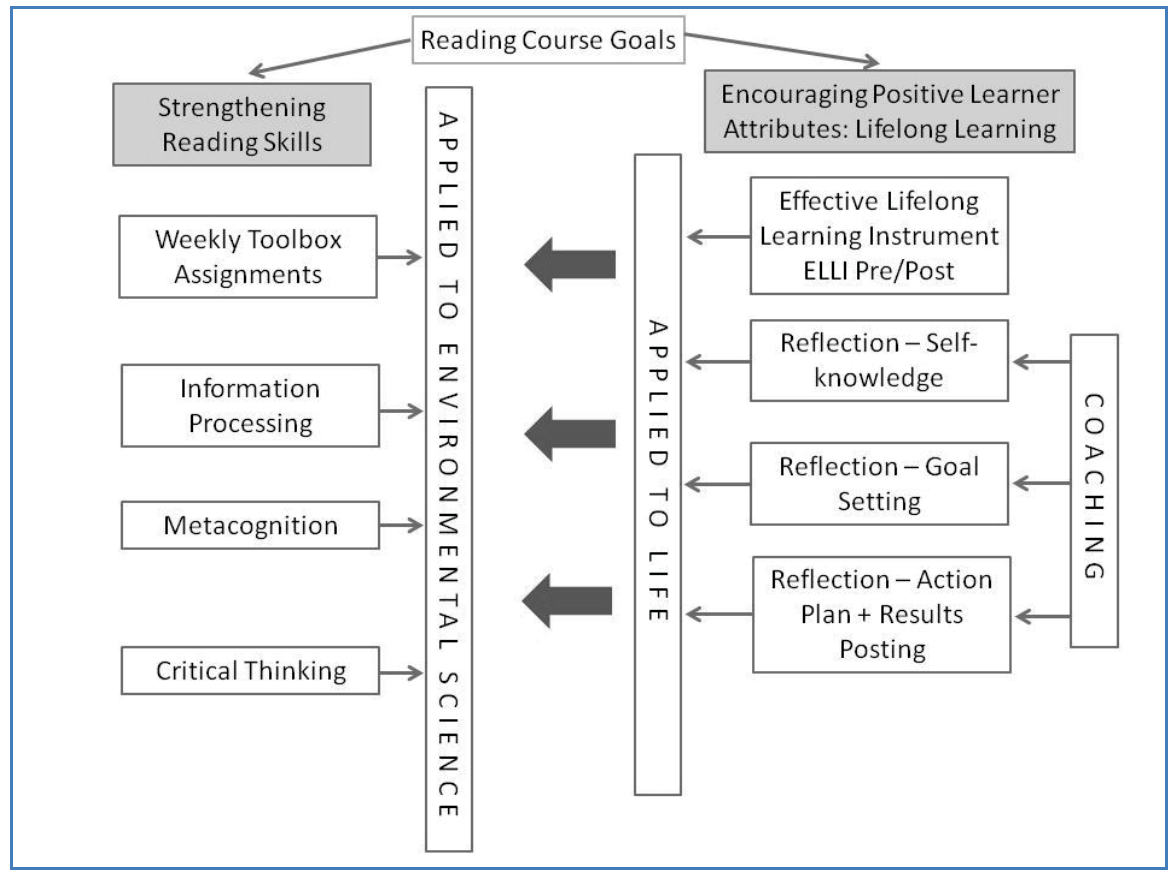

Figure 1. Paired course design framework. 


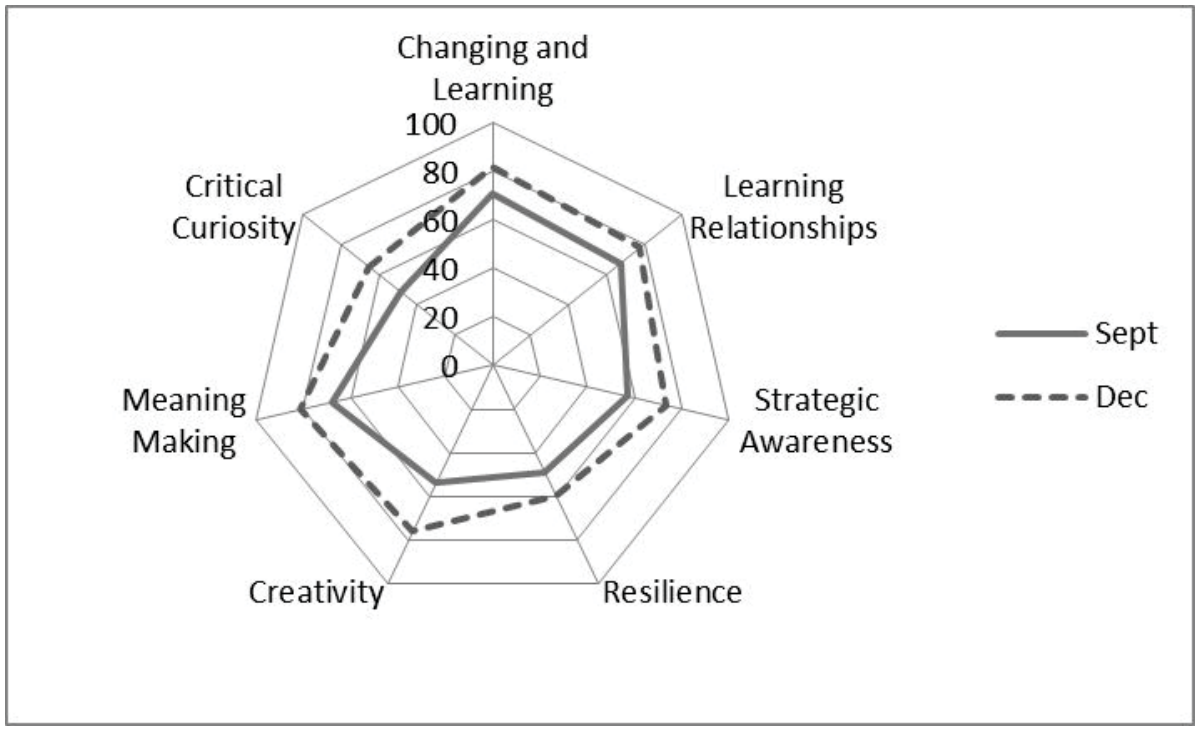

Figure 2. Spider diagram of student pre- and post-semester ELLI scores.

Appendix

\section{Reading Course Activities}

\section{Developing Reading Skills}

The course "toolbox assignments" were meant to help students apply strategies learned in class to the environmental science content. Cornell notes, concept mapping, outlining, reading graphs and charts, and vocabulary development were topics covered to build their information processing skills. Students also learned how to become more aware of their metacognitive processes while reading and studying for exams (Karpicke, Butler, \& Roediger, 2009). Where were they getting stuck? What questions did they have while reading? What reading/learning strategies were students choosing to use and why? How prepared were they for upcoming exams? Finally, critical thinking and other deep processing techniques, using the Paul and Elder (2006) framework were used to help them develop higher-order reading and thinking skills. One example of each level of activity follows:

Information Processing. Vocabulary development using the SEE-I strategy (Nosich, 2012)

Students fill out an index card for each concept.

S: State it (briefly, clearly, precisely explain the term) "This concept is..."

E: Elaborate it (explain more fully in your own words) "In other words..."

E: Exemplify it (create your our own example) "For example..."

I: Illustrate it (create a metaphor, simile, an analogy, a diagram, a concept map, etc.) "This concept is like..."

Extension activity: This can be turned into a good One-Minute paper to review new concepts at the end of class - Have them fill out a SEE-I on an index card on a main concept from the class and then write a short paragraph with a longer description. 
Metacognition. Are you sure you are ready for the exam? (Karpicke, Butler, \& Roediger, 2009)

Students get recognition of words confused with comprehension. They often do not study enough, but think they are ready because they recognize the words. In this activity, students get a blank answer sheet, divided into sections that are going to be covered on the exam. Each section has a heading with that topic. Multiple choice questions (of varying difficulty levels) are asked for each topic. Students fill in the answer sheets and then they self-score their answers. They tally up the points earned for each topic and then circle the areas of weakness indicating review that is needed.

Critical Thinking. Socratic Questioning (Paul \& Elder, 2006) Have student notice the intellectual moves within and between the series of questions.

- What is ... e.g. INSERT your CONCEPT HERE

- To answer this question, do we need to answer other questions first?

- Who is in the best position to know what this means? Why?

- Why is this question important?

- How does the answer change when we consider it in different contexts - at work, at school, in the world?

- How would our answer change if we consider it from an "insider" or "outsider" or other perspective?

- What might influence each group's perspective?

- What would you say to someone who says, "xyz" about this concept? What makes people feel this way? What are possible implications of this statement?

- How does one acquire an understanding of concept in the real world?

- Do you think it is important?

- How would you finish this sentence: This concept is like....

- How would you finish this sentence: The opposite of this concept is is.....

- If I could draw a symbol for this concept, it would be... because...

Now, take a new course concept and begin designing a Socratic discussion - coming up with 4 questions that you could ask - look for follow-up questions to have ready - practice with a partner.

Extension activity: Students choose one concept from your content course and create a discussion, using similar questions as those above. Choose several concepts from class and have students use the above as a model to build an in-class discussion that they lead in the whole class or as smaller groups.

\section{Developing Lifelong Learning Attributes}

What follows is an example of a lesson planning cycle for one of the lifelong learning dimensions. After that, a video link is provided which contains more examples for the other dimensions.

Critical Curiosity. An example of a two-week sequence based on the Critical Curiosity dimension began with a general description from the ELLI literature, followed by an in-class discussion about their ELLI score and the role it might play in their lives and experiences. Students then took another curiosity inventory, the CEI-II, and discussed the notion further based on the new description which takes into account a person's willingness/comfort level with stretching into new experiences and their comfort level with uncertainty (Kashdan et al., 2009). After this discussion and activity, students received a reflective prompt geared towards enhancing their self-awareness and helping them to make a concrete plan to grow 
in that dimension. Homework would be to implement the plan during the upcoming week and discuss outcomes at the next session. Coaching by the faculty member and/or peers took place in class and online in journal entries. The second week of this particular cycle, we used a scholarly journal article on the role of curiosity in academic success to frame a discussion about the academic connections to curiosity (von Stumm, Hell, \& Chamorro-Premuzic, 2011). The final activity was a strategy to encourage curiosity called What-Why? The instructor places a statement on the board pertaining to something relevant happening in the class. "Students often do not like to speak up in class." The instructor asks, "WHY?" A general discussion ensues and the consensus answer is then placed on the board. "Students feel anxious about giving a wrong answer." The instructor again asks, "WHY?" and the cycle continues as long as the discussion is productive. It is important to debrief the activity to discuss how and when the strategy could be used in personal and academic settings.

More examples. A description of additional examples of lifelong learning integration activities in each dimension was recorded at https://www.youtube.com/watch?v=gK5I_68g0X8 and is called ELLI Integration (Shaffer, 2014).

Suzanne C. Shaffer is an instructional designer at the Penn State York Campus and has also taught developmental ESL and college reading courses since 1997. She is currently taking courses in Penn State's graduate certificate in Institutional Research including coursework in measuring student learning outcomes and evaluating programs and enrollment management. She holds Master's degrees from Penn State University in Instructional Systems and from Indiana University (Bloomington) in Language Education.

Barbara Eshbach is the Head Librarian of the Penn State York Library with a Master's degree in Library Science from Clarion University of Pennsylvania. Ms. Eshbach's research interests lie in first-year college student success and the role of the library in student support.

Dr. Jorge A. Santiago-Blay earned his MA (Botany) and PhD (Entomology) at the University of California at Berkeley. He is a Research Associate at the Smithsonian Institution's National Museum of Natural History in Washington, DC, http://paleobiology.si.edu/staff/individuals/santiagoblay.html. There he pursues his interests in numerous areas of biology and includes undergraduates as well as volunteers in his research. With over 30 years of teaching experience, SantiagoBlay has developed an avid interest in best practices in teaching and learning. Also, he enjoys communicating science to the broad public. Santiago-Blay serves as Editor-in-Chief of the peer-reviewed, scientific journal, Life: The Excitement of Biology. 